\title{
Importance of Customer Relationship Management in Customer Loyalty (Brangkal Offset of East Java, Indonesia)
}

\section{ChamdanPurnama ${ }^{\mathrm{a}}$}

${ }^{a}$ President School of Economics, Al-Anwar Mojokerto, Indonesia

\begin{tabular}{|c|c|}
\hline & ABSTRACT \\
\hline $\begin{array}{l}2015 \text { Research Leap/Inovatus Services Ltd. } \\
\text { All rights reserved. }\end{array}$ & $\begin{array}{l}\text { This study examines the importance of customer relationship management to increase } \\
\text { customer loyalty. Study uses two years' data on 71customer (respondents)of Brangkal Offset } \\
\text { chosen on the basis of random samplingtechnique. Results of this investigation indicate that }\end{array}$ \\
\hline $\begin{array}{l}\text { DOI: } 10.18775 / \text { jibrm.1849-8558.2015.11.3004 } \\
\text { URL: http://dx.doi.org/10.18775/jibrm.1849- }\end{array}$ & $\begin{array}{l}\text { important aspects of customer relationship management those are people, process and } \\
\text { technologyboth partially and simultaneously have an impact on the increase of customer loyalty. }\end{array}$ \\
\hline
\end{tabular}
$\underline{8558.2015 .11 .3004}$

Keywords:

Customer relationship management

Customer loyalty

Indonesia

\section{Introduction}

The business strategy is currently focused on the creation of a trust or confidence of customers to the company. The customer is a very valuable asset for the company.If the company loses its customers, it will not only lose its profit, but also its possible sales that may happen in the future will be in at risk. Acquired loyal customers are the biggest advantage of thecompany becausethe company can sell more goods or services to those loyal customers who have already tried the relevant goods or services of the company and formed some knowledge on them. Besides, the company has spent a lot of effort to establish a relationship with the customer.

The best way to build relationships with customers can be realized by building a customer relationship management. Customer relationship management is a type of management that specifically discusses the theory about the handling the relationship between the company and its customers with the goal of increasing the company's value in the eyes of its customers. Customer relationship management embraces all aspects of dealing with prospective and current customers, including the call center, sales force, marketing, technical support and field service. As the wording implies, customer relationship management is an activity aimed at obtaining a relationship with the customer to be able to provide a significant advantage for the company.

Research conducted in Taiwan for 58 hotels analyze customer relationship management in the form of operational processes by Edward (2010) states that the operational 
processes both increase profitability and maximize customer relationships and operational capabilities can accelerate the process of customer ordering. Research conducted by Borle et al (2010) showed that the customer community management program can increase the number of customers the companytargets.

Research in the US by Krasnikov (2009) conducted on commercial bank ofthe US examines the impact of the implementation of customer relationship management in two company's performance, operational performance, cost efficiency and their ability to generate profit (profit efficiency). Results of the study found that implementation of customer relationship management improve cost efficiency and increase profits.

The results of the research conducted in Egypt by Battor (2010) reinforces the view that developing good relationships with customers can improve a company's ability to innovate. Relationship with customers is one indicator of customer relationship management.

Purnama (2014: 242) in his study conducted in Indonesian small clothing industrystates that attitude, intelligence, emotion, skills and knowledge of employees altogether can influence the ability of the employee. Results of this study prove that the skills and knowledge of employees affect the ability of businesses in the works and will also increase production.

Prasad (2008) examined the effect of relational marketing attributes such as trust, commitment, communication, empathy, and conflict on relationship quality and customer loyalty. The study was conducted on 300 customers of retail companies in India. The research proves that the quality of relationships has a significant effect on customer loyalty.

Few studies conducted in Taiwan, the US, India, Egypt and Indonesia are related to customer relationship management and customer loyalty relationship. Through customer relationship managementcompanies can build closer relationships with customers, and the company can learn the needs of customers and provide a selection of products or services in accordance with their request. As expressed by Kotler and Keller (2007: 189), customer relationship management is "the process of managing detailed information about individual customers and carefully managing all customer touch points in order to maximize customer loyalty". This study is quite the same with other studies. The distinguishing feature of this study is that previous studies looked at the performance in terms of costs, the ability to innovate and company's profits and customer relationships and they were carried on the example of retail, food, hospitality and banks. This study has been carried out in the example of an offset servicecompanyto measure its performance in terms of customer loyalty.

At the core of customer relationship management, there is a way to analyze customer behavior. From this analysis, the company can finally be able to take ways how to serve customers in a more personalized way so that customers become loyal to the company. To be able to maintain a loyal customer and in order not to lose them to a competitor, the company should establishgood relationship with the customers and should try toincrease company's value in the eyes of its customers. This endeavor requires a precise and efficient strategy from the company to know its customers betterto serve them better. Customer relationship management is not a new,recently invented conceptby consultant's world. Customer relationship management is a fundamental paradigm of how to look at the customer and how to better satisfy customers through a harmonious relationship and quality.

\section{Literature Review}

\subsection{Customer Relationship Management}

According to Widjaja (2008: 45),customer relationship managementis a comprehensive approach to create, maintain, and developrelationships with customers. According to Buchari (2004: 271),customer relationship management is a process to acquire, retain and grow the most profitable customers. According to Frederick (2000: 2),customer relationship management is the process of modifying consumer behavior over time and learning from each interaction, change, taking care of customers, and strengthening ties with them. According to understanding of the customer relationship management by Luke (2001:3), it is "an activity that involves the entire human resources to retain existing customers; a strategy to cultivate and maintain relationships with customers; an attempt to determine the wants and needs of customers".

Based on a variety of definition ofcustomer relationship management from above, it can be concluded that customer relationship management is a business strategy of the company to establish relationships with customers and provide satisfactory services for customers. Luke (2001: 116)dividesthree main components, namely: People, Process and Technologyof customer relationship management into

\subsubsection{People}

In this case the employee has a very important role in the sustainability of the implementation ofcustomer relationship management, because they are implementing customer relationship management as an activity or desire ne companies. With the implementation of customer relationship management has been a change in marketing paradigm, when previously, the production becomes the main focus in the implementation of customer relationship management, the customer is the main focus. As for what needs to be addressed from a aspect people is the enthusiasm, knowledge, skills, friendliness, and responsiveness to the customer's own employees.

\subsubsection{Process}

Implementation of customer relationship management changes the complete business processes that have beenin place for a long time.It changes both business processes that directly involve customers or not. On the whole, customer relationship management business functionality is focused on the customer. Customer relationship management process includes:

1. Identification: Identification of customers and prospects based on existing data, customers who are profitable, he lived where and why he was favorable. Most companies only care how big the benefits of its customers without knowing who are the customers that have been profitable. There are a few things 
to know about the customer such as: (a) Firm graphic: namely information about customers or companies that do business with us. Such as: address, business, zip code and so on. (b) Demographic and psychographic: the information concerning contact person (customers). (c) Info graphic: how to contact Pearson wanted a way of interaction in obtaining information about him.

2. Differentiation: Segment customers based on behavior, demographics, and customer expectations.

3. Interaction: Make the best plan for interacting with customers, and then create customer loyalty programs, crossselling, and so on. The longer the interaction occurs, the more know each other, the more reluctant customers moving to competitors because customers will find it hard to start a new relationship with a competitor. Interaction can be done by email, telephone and fax, mail, and face to face.

4. Personalization: Products and loyalty programs tailored to the wishes of customers who continuously. Using all the information that has been obtained prior to making goods and services in accordance with the wishes and needs of customers.

\subsubsection{Technology}

Technology has a role in customer relationship management. Firstly, it is building a data base ofcustomers ranging from the operating system up to the transaction. Secondly, to analyze who the customer is themost good; he bought what, how often. Third, implement the activities of sales, marketing, and customer service by integrating different communication channels (operational customer relationship management).

Customer loyalty has an important role in a company, the longer the company maintains a loyal customer, the greater the profit generated. This is the main reason for a company to retain customers. When companies spend less in order to obtain new customers, the company can also spend money to improve the quality of products or services continuously. In turn, it also can help make customers become more loyal.

Having a loyal customer is the ultimate goal of all companies, but most companies do not realize that customer loyalty is formed through the stages starting from looking for potential customers to the Customer Advocate will bring benefits to the company. Customer loyalty according to Griffin (2005: 4) is: "Customer loyalty is defined purchasing buying behavior nonrandom disclosed from time to time by some of the decision-making unit". According toTjiptono (2000: 110) says that: "Customer loyalty as a customer commitment to a brand, the store, the supplier is based on a very positive attitude and reflected in repeat purchases consistent." Meanwhile, according to Widjaja (2008: 6), customer loyalty is attachment to a brand, store, manufacturer, service provider, or other entity based on a favorable attitude and a good response as repeat purchases".

From the above definition, it can be concluded that the more loyalty leads to behavior (behavior) compared with an attitude (attitude) and a loyal consumer purchasing behavior will exhibit behavior that is defined as the purchase of a regular and behaviors throughout the show by the decision maker.
Loyal customer is an asset to the company and to determine the company's loyal customers to be able to offer products or services that can meet customer expectations and satisfy its customers, when customers make a purchase action repeatedly and regularly then the customer is a loyal customer. This is reinforced by the statement of Griffin (2005: 31), which states that the characteristics of loyal customers include:

Make purchases on a regular basis or regular.

Buying outside the line of products or services.

Recommend to others.

Not easily affected competitor product appeal.

\section{Research Methods}

This study is classified as explanatory research. Approach to research using correlation design. Draft correlation is useful to analyze the relationship between one variable to another variable, or how a variable affects other variables. The study population was Brangkal Offset customers since the last two years as many as 250 customers. Usage sample technique is to use simple random sampling. The size of the sample to be studied using questionnaires as the data collection tool according to population numbers mentioned above, which amounted to 250 people, while the determination of the number of samples is done by using the formula of Slovin Umar (2002: 146). Based on the calculation of the number of members of the sample in this study were 71 respondents. In this study the analysis of the test data validity, reliability and classical assumption of all items of questions (instruments) as well as multiple regression analysis to see the effect by using SPSS for Windows version 16.0.

Model equations to see the influence of variables customer relationship management, which include: Aspects People, process and Technology on customer loyalty are as follows:

$$
\mathrm{Y} 1=\mathrm{a}+\boldsymbol{\beta} 1 \mathrm{X} 1+\boldsymbol{\beta} 2 \mathrm{X} 2+\boldsymbol{\beta} 3 \mathrm{X} 3
$$

Description: $\mathrm{Y} 1=$ Customer Loyalty, $\mathrm{a}=$ Constanta, $\mathrm{X} 1=$ Aspects People, X2 = Aspects Process, X3 = Aspects Technology, $(\boldsymbol{\beta} 1,2,3,=$ Coefficient that describes the path of the influence of the independent variables to the dependent variable

\section{Results}

\subsection{Test Results of Validity and Reliability}

The test results question the validity of the entire item (instrument) study of samples collected and processed using SPSS analysis tools $16: 00$ prove that all items are valid questions. The analysis showed that all items have a question of correlation greater than 0.40 and have significant value Pearson smaller than $\alpha(0.05)$. Thus, all the indicators used to dig respondents on variables customer relationship management which include: the aspect people, process and technology and customer loyalty is valid.

While the reliability test results that have been performed using SPSS 16.0 analysis tool of data that can be collected, it is known that the value of Cronbach's alpha all variables in this study is greater than 0.70 so it can be said that the reliability is 
acceptable even better. Thereby, it can be concluded that the results of measurements that have been done are reliable for further analysis.

\subsection{Test Results of Regression Analysis}

In this regression test in addition to looking for the coefficient of determination can also be used to test the hypothesis, testing the hypothesis with a simple regression and $\mathrm{t}$ test with the rules $\mathrm{t}$ test $>_{-} \mathrm{t}$ table rejected significant meaning, and if $\mathrm{t}$ test $>_{-} \mathrm{t}$ table $\mathrm{Ho}_{\mathrm{i}}$ is accepted, it means insignificant. Testing this hypothesis using regression 3 doubles, and regression testing and $\mathrm{f}$ test, with the rules $\mathrm{f}$ test $>_{\text {_ }} \mathrm{f}$ table Ho rejected significant meaning, and if $\mathrm{f}$ test $>_{-} \mathrm{f}$ table Ho is accepted, it means insignificant.

Test results of regression statistical analysis tools SPSS version 16.0, to examine the effect of customer relationship management which include: (X1) People, (X2) Process and (X3) Technology on customer loyalty (Y1) like the following table:

Table 1: Result of ANOVA; the influence of Aspects People, Process and Technology to Customer Loyalty

Model Summary

\begin{tabular}{ccccc}
\hline Model & R & R Square & $\begin{array}{c}\text { Adjusted R } \\
\text { Square }\end{array}$ & $\begin{array}{c}\text { Std. Error } \\
\text { of the }\end{array}$ \\
\hline & & & & Estimate \\
1 & $.0878^{\mathrm{a}}$ & .772 & .762 & 1.83985 \\
\hline
\end{tabular}

Table 2: Test Result Coefficient the influence of Aspects People, Process and Technology to Customer Loyalty

ANOVA $^{\text {b }}$

\begin{tabular}{ccccccc}
\hline Model & & $\begin{array}{c}\text { Sum of } \\
\text { Squares }\end{array}$ & df & $\begin{array}{c}\text { Mean } \\
\text { Square }\end{array}$ & F & Sig. \\
\hline \multirow{2}{*}{1} & Regression & 766.780 & 3 & 255.593 & 75.507 & $.000^{\mathrm{a}}$ \\
& Residual & 226.797 & 67 & 3.385 & & \\
& Total & 993.577 & 70 & & & \\
\hline & ${ }^{\text {a. }}$ Predictors: (Constant), X3, X1,X2 \\
& bependent Variable: Y1
\end{tabular}

Table 3: Test Result of influence between the aspect people of customer loyalty

\begin{tabular}{|c|c|c|c|c|c|c|}
\hline \multicolumn{7}{|c|}{ Coefficients $^{a}$} \\
\hline \multirow[t]{2}{*}{ Model } & & \multicolumn{2}{|c|}{$\begin{array}{c}\text { Unstandardized } \\
\text { Coefficients }\end{array}$} & \multirow{2}{*}{$\begin{array}{l}\text { Standardi- } \\
\text { zed Coeffi- } \\
\text { cients } \\
\text { Beta }\end{array}$} & \multirow[t]{2}{*}{$\mathbf{t}$} & \multirow[t]{2}{*}{ Sig. } \\
\hline & & B & $\begin{array}{l}\text { Std. } \\
\text { Error }\end{array}$ & & & \\
\hline \multirow[t]{4}{*}{1} & (Constant) & 32.125 & 3.003 & & 10.697 & .000 \\
\hline & X1 & .303 & .049 & .454 & 6.153 & .000 \\
\hline & $\mathrm{X} 2$ & .189 & .058 & .258 & 3.389 & .001 \\
\hline & $\mathrm{X} 3$ & .201 & .042 & .345 & 4.846 & .000 \\
\hline
\end{tabular}

Test Result of influence between the aspect people of customer loyalty
Table 3 describes the level of influence between the variables of the aspect people (X1) on customer loyalty (Y) which is calculated by the coefficient of determination (R2) was 0.772 . This indicates a strong influence on the aspect people of customer loyalty. While significant levels (measured of probability) gives the figure of 0.000 . Because the probability is much below 0.05 , then the influence of the aspect people of customer loyalty significantly. Based on table 3 of the ANOVA test or $t$ test, was obtained t test was 26.121 withbecause the probability of a significant level of 0.000 is much smaller than 0.05 , so the regression model can beused to predict customer loyalty.

Table 3 illustrates that the regression equation as follows: $\mathrm{Y} 1=32,125+0.303 \mathrm{X} 1$

Description:X1 = Aspect people; $\mathrm{Y} 1=$ Customer loyalty

Constants of 32,125 states that if there is no increase in the value of the variable aspect of people (X1), then the value of customer loyalty (Y1) is 32,125. Regression coefficient for 0.303 menyatakan that each additional score or the value of the aspect people will provide increased customer loyalty by 0.303 .

Based on the calculation of the value, it can be said that Ho is rejected. Because $t$ test $>t$ table $=6.153>1.670$. Seen in the sig column in the table is 0.000 or probability values far below 0.05. Because $t$ test $>t$ table or 6.153>1.670, then Ho is rejected it means a significant regression coefficient or the aspect people significant direct effect on customer loyalty.

Test results of influence between the aspect processes to customer loyalty 
Based on the table 1 that the influence of the variable aspect of the process (X2) on customer loyalty (Y1) is calculated with a coefficient of determination (R2) was 0.772 . This shows the strong influence of the aspects of the process to customer loyalty. While significant levels (measured by probability) give the figure 0,001 . Because the probability is much below 0.05 , then the influence of the aspect of the process towards a significant customer loyalty. Based on table 3 of the ANOVA test or $t$ test, was obtained t count is 3.369 to 0.001 due to a significant level of probability $(0.000)$ is much smaller than 0.05 , so the regression model can be used to predict customer loyalty.

Table 3 illustrates that the regression equation as follows:

$$
\mathrm{Y} 1=32,125+0.189 \mathrm{X} 2
$$

Description: $\mathrm{X} 2$ = Aspects process; $\mathrm{Y} 1=$ Customer loyalty

Constants of 32,125 states that if there is no increase in the value of the variable aspect of the process (X2) the value of customer loyalty (Y) is 32,125. Regression coefficient of 0.189 states that each additional score or value aspects of the process will provide increased customer loyalty by 0.189 .

Based on the calculation of the value $t$ test $>t$ table or $3.369>1.670$, and $0.001 \mathrm{sig}$ value or probability is much below 0.05 , then Ho is rejected means regression coefficient significant or significant influence over the process aspect.

Test results of influence between the aspects technological of customer loyalty

Based on the table 1 that the influence between the variables of the technological aspects (X3) on customer loyalty (Y1) is calculated with a coefficient of determination (R2) was 0.772. This shows the strong influence of the technological aspects of customer loyalty. While significant levels (measured by probability) give the figure of 0.000 . Because the probability is much below 0.05 , then the influence of the technologicalaspects of customer loyalty significantly. Based on table 3 of the ANOVA test or $t$ test, was obtained $t$ count is 4.846 to 0.001 due to a significant level of probability $(0.000)$ is much smaller than 0.05 , so the regression model can be used to predict customer loyalty.

Table 4 illustrates that the regression equation as follows:

$$
\mathrm{Y} 1=32,125+0.201 \mathrm{X} 3
$$

Description:X3 = Aspects of technology; $\mathrm{Y}=$ Customer loyalty

Constants of 32,125 states that if there is no increase in the value of the variable aspect of technology (X3) then the value of customer loyalty (Y1) is 32,125 . A regression coefficient of 0.201 states that each additional score or value aspects of the process will provide increased customer loyalty by 0,201 .

Based on the calculation of the value $t$ test $>t$ table or 4.846> 1.670, and sig 0,000 or probability is much below 0.05 , then Ho is rejected means regression coefficient significant or technological aspects significant influence.
Test results of influence between the aspects people, process and technology of customer loyalty

Based on the table 1 that the influence between the variables of the aspect people (X1), aspects of the process (X2) and technological aspects (X3) on customer loyalty (Y1) is calculated with a coefficient of determination (R2) was 0.772 . This suggests a strong influence on the aspect people, process and technology aspects of the customer loyalty. While significant levels (measured by probability) give the figure of 0.000 . Because the probability is much below 0.05 , then the effect of jointly between the aspect people, the aspect of the process and technology aspects of the customer loyalty significantly.

According to the table 2 of the ANOVA test or $\mathrm{f}$ test, was obtained f test was 75.507 with a significant level of 0.000 for the probability $(0.000)$ is much smaller than 0.05 , which means the aspect people, aspects of the process and technology aspects have a significant effect on customer loyalty.

From Table 3 illustrates that the regression equation as follows:

$$
\mathrm{Y} 1=32,125+0.303 \mathrm{X} 1+0.182 \mathrm{X} 2+0.201 \mathrm{X} 3
$$

Description: $\mathrm{X} 1=$ Aspect people; $\mathrm{X} 2$ = Aspects process; $\mathrm{X} 3$ = Aspects of technology; Y1 = Customer loyalty

Constants of 32.125 states that if there is no increase in the value of the variable aspect people (X1), aspects of the process (X2) and technological aspects (X3), then the value of customer loyalty (Y) is 32,125 . Regression coefficient for the aspect people of 0,303 menyatakan that each additional score or the value of the aspect people will provide increased customer loyalty by 0.303 . While the regression coefficient for the aspects process of 0.189 states that each additional score or value aspects of the process will provide increased customer loyalty by 0.189 . While the regression coefficient for the aspects technological of 0.201 states that each additional score or value aspects of technology will provide improved customer loyalty amounted to 0.201 . When viewed from three aspects, aspects people, aspects of the process and technology aspects that most influence on customer loyalty is the aspects people of the coefficient for 0,303 second sequence is technological aspects with a coefficient of 0.201 and the third is the aspect of the process with a coefficient of 0.189 .

\section{Discussion}

In this section we will discuss the research findings are described in the previous section. The discussion be based on empirical findings and theories and previous research relevant to the research conducted. This discussion is intended to explain the relationship between the independent variables and the dependent variable. Based on the test using SPSS 16.0 for Windows through regression analysis, the results of testing the validity and reliability of the research instrument produces valid and reliable instrument. Results of this study to answer that very good regression analysis model to explain the effect of customer relationship management. That include: aspect People, process and technology on customer loyalty in the Brangkal Offset. 
By analyzing the effect of customer relationship management. That include: aspect people, process and technology on customer loyalty is expected to be able to gain an understanding of the process through customer relationship management that management. That include: Aspect people, process and technology by management and its effect on customer loyalty in the Brangkal offset. In this research linking the four variables proposed in the conceptual model. Four of these variables include: the independent variables people, process and technology and the dependent variable customer loyalty. The indicators of the four variables were identified, all eligible both validity and reliability. In this study discovered the influence of variables management. That customer relationship include: Aspect people, process and technology on customer loyalty in Brangkal Offset as test results of the regression analysis model. An explanation of the effect of customer relationship management include aspect people, process and technology on customer loyalty in Brangkal Offset is as follows:

\section{Effect of the aspect people of customer loyalty}

Through regression analysis found that customer loyalty is influenced by aspect people. Based on the above test results obtained that all the indicators used as a measure of the variable in explaining aspect people, namely: enthusiastic, knowledge, skills, friendliness and responsiveness of employees together can be used as a measurement variable aspect people.

It can be concluded that the results of testing by regression analysis through SPSS 16.0 shows that the aspect people that include indicators of enthusiasm, knowledge, skills, friendliness and responsiveness to spur employees to improve customer satisfaction and therefore contributes to customer loyalty. These findings Sedana with Battor (2010) that developed a close relationship with the customers improve the company's ability to innovate. Thereby increasing customer satisfaction and ultimately have an impact on customer loyalty. These findings are also in accordance with what is presented in Tjiptono (2003: 95) the creation of customer satisfaction can provide several benefits, including the relationship between companies and consumers to be harmonious, provide a good foundation for repeat purchases and create customer loyalty and provide recommendations by word of mouth (word-ofmouth) that benefit enterprises. At the consumers are basically all the same, regardless of the money they spend, regardless of the products they buy, they have the right to get the best service. If they are disappointed, they will not hesitate to vilify companies in front of many people. Oneindicator of the level of customer satisfaction is a 'repeat order'. If consumers are satisfied when buying a product for the first time, they will come again to buy it at a greater amount than the first order.

\section{Effect of the process aspect of customer loyalty}

Based on the results of the regression analysis found that customer loyalty is influenced by aspects of the process. Based on the above test results obtained that all the indicators used as a measure in explaining aspects of the process variables, namely: identification, differentiation, interaction and personalization together capable of being used as a measurement variable aspects of the process. It can be concluded that the test results and regression analysis through SPSS 16.0 indicates that aspects of the process including identification, differentiation, interaction and personalization can be a positive influence on customer loyalty.

These findings show that the results are in line with what is mentioned by Edward (2010) which states that the process of analysis, operations, and the ability of both analytical capabilities, increase profitability, maximize customer relationships, operational capability, cut in the booking process can reduce costs so as to increase sales. In terms of processes and procedures, companies should define more clearly the target market targeted and procedures in more detail in serving consumers. It is important that employees who deal directly with consumers to have clear rules about how to serve their customers. Moreover, one thing that is how companies connect between customer satisfaction with employee performance. That is not only a slogan and jargon, but the customer service process into a system that must be exercised by all employees.

\section{Effect on the technological aspect of customer loyalty}

Based on regression analysis found that customer loyalty is influenced by technological aspects. Based on the above test results obtained that all the indicators used as a measure of the variable in explaining technological aspects, namely: speed, confidence and satisfaction of use of technology together can be used as measurement variable technological aspects. It can be concluded that the test results and regression analysis through SPSS 16.0 indicates that the aspect of technologies that includes speed, confidence and satisfaction of the use of technology can be a positive effect on customer loyalty.

These findings show that the results are in line with what was mentioned by Prasad (2008) examined the effect of relational marketing attributes such as trust, commitment, communication that can affect customer loyalty. With customer relationship management applications, we can do the sales and service via the web so the chance of global sales without the need to provide a special effort to support the sales and service. Internet enables remote communication and global nature, so that the company and its customers or potential customers can interact without being limited by time and place. Through the utilization of the Internet, a company can reach consumers on a global scale with limited capital, and conduct business activities such as promotion, product introduction, product description, product price to sales transactions that can be more indulgent products consumers.

In addition the company can perform an analysis of the customer based on specific criteria such as the analysis can be generated very diverse based on the data of incoming information, in the form of questions, complaints, or suggestions customers often helps the company to improve its products and services. Can display a warning or reminder as say happy birthday earlier than the partner or customer contacts so as to make the customer flattered, this is one example of the usefulness warming or reminder on the customer relationshipmanagement system. Not limited only to pamper the customer, warning, or a reminder can also be used to remind the customer on certain events, such as due date product / service specific, it will help facilitate business activities so that the company can build a relationship that is directly with the consumer (direct marketing).

Effect of the aspects people, process and technology to the Customer loyalty 
Based on regression analysis found that customer loyalty is influenced by aspect people, Based on the above test results obtained that all the indicators used as a measure of the variable in explaining aspect people, aspects of the process and technology aspects together can be used as a measurement variable. It can be concluded that the test results and regression analysis through SPSS 16.0 shows that the aspect people, aspects of the process and technology aspects together influence on customer loyalty.

These findings are in line with Kotler and Keller (2007: 189), Customer relationship management is "the process of managing detailed information about individual customers and carefully managing all customer touch points in order to maximize customer loyalty". Customer relationship management applications provide information can increase revenues and profits. Customer relationship management can do sales and service via the web so the chance of global sales without the need to provide a special effort to support the sales and service. Additionally customer relationship management enables companies to leverage information from all points of contact with customers, whether it is via web, call center, or through enabling sales staff or service at a cheaper cost. Automation of sales and service processes can reduce the risk of decline in the quality of services and reduce the burden on cash flow. The use of web technology and a call center, for example, will reduce red tape and costs as well as administrative processes that may arise. With sales capability via the web, then the barriers of time, geography, until the availability of data sources can be ruled out to accelerate the sale of such products. This is done by Brangkal Offset Mojokerto in increasing sales and improving customer loyalty.

\section{Conclusion}

From the results of research and discussion of the influence of customer relationship management to customer loyalty can conclude that customer relationship management is needed by the company on the grounds: First, it is a change of Production Driven Company into shape Customer Driven Company. These changes occur because the customer who will decide which companies will be chosen based on the company's ability to meet the needs of its customers. Second, the customer determines a business organization that must be managed. Without customers a business may not be able to walk. Therefore, the customer must be managed properly so that customers be satisfied, and be loyal to the company. Third, the customer has a need or preference which different from one another. Customer relationship management to know that different customers representing the value of the company are also different. Thus, the purpose of customer relationship management is the customer knows best and believes the company will increase the understanding of their needs as individuals, to meet their expectations, and make their lives changed. Fourth, the cost to acquire customers 6 to 7 times more than the cost to maintain it, meaning that each customer has its own uniqueness, they have the desire, the demand, which different capabilities and characteristics, so knowing who the customer are an obligation. While the last / fifth, customer relationship management is not just serving, with the database, the company should be able to serve its customers better. A good customer relationship management should be able to provide emotional value besides relations benefit to the customer.

\section{References and notes}

1. Bettor, Moustafa, 2010. The impact of customer relationship management capability on innovation and performance advantages, Tanta University, Egypt Journal of Marketing Management Vol. 26, Nos. 9-10, August, 842-857. CrossRef

2. Borle, Sharad; Singh, Siddharth S.; Jain, Dipak C. 2008, Customer Lifetime Value Measurement, Management Science, Vol.54 No. 21, pp. 100-112 CrossRef

3. Buchari Alma 2004, Marketing Management and Marketing Services, Bandung: Alfa beta.

4. Edward CS, 2010. The impact of customer relationship management through implementation of information systems, Department of Travel Management, National Kaohsiung University of Hospitality and Tourism, Taiwan, Republic of China Total Quality Management Vol. 21, No. 11, November, $1085 \neg 1102$

5. Frederick Herzberg 2000, Organizational Behavior, Tenth Edition, New Jew Jersey: Prentice Hall Griffin, J, 2005, Customer Loyalty, Lexington Books, New York.

6. Prasad JS and AR Aryasri, 2008. Versus Relationship Marketing Relationship Quality and Customer Loyalty In Food Retailing, Pranjanavol 11, No 2,

7. Philip Kotler \& Kevin Lane Keller (2007). Marketing Management. 13th edition. Pearson, Prentice Hall

8. Krasnikov Alexander, Satish Jayachandran, and V. Kumar, 2009. The Impact of Customer Relationship Management Implementation on Cost and Profit Efficiencies: Evidence from the US Commercial Banking Industry, Journal of Marketing Vol. 73 (November), 61-76

9. Luke, Paul Ade, 2001 Seminar Papers: Customer and Partner Relationship Management, Telematic Research Group.

10. Philip Kotler and Kevin Lane Keller, Interpreting Benjamin Molan, 2007, Marketing Management, Twelfth Edition, Volume 1, PT. Index.

11. Purnama Chamdan and RahmahMihamida, (2014) Empowering Small Industry in Improving Business Success, Lap Lambert Academic Publishing, Saarbrucken Germany

12. Sugiyono 2008, Statistics for Business Research, Bandung: Alfabeta.

13. Tjiptono Fandy, 2000, Marketing Strategy, Yogyakarta: Andi Offset.

14. Umar, Husein, 2002, the Marketing Research and Consumer Behavior, Jakarta: GramediaPustakaUtama.

15. Usmara, A, 2003, the New Strategy Marketing Management, Amoro Book, Yogyakarta

16. Widjaja Amin Tunggal 2008, Customer Relationship Management (Concept and Case), Jakarta: Harvarindo 